\title{
Haptic Spectatorship and the Political Life of Cruelty, or, Antonin Artaud "Signaling Through the Flames"
}

\section{R. D. Crano}

\section{The separation of culture and life in interbellum France}

The first words of Antonin Artaud's The Theater and its Double, first published in France in 1938, read as follows:

\begin{abstract}
Never before, when it is life itself that is in question, has there been so much talk of civilization and culture. And there is a curious parallel between this generalized collapse of life at the root of our present demoralization and our concern for a culture which has never been coincident with life, which in fact has been devised to tyrannize over life. ${ }^{1}$
\end{abstract}

It seems peculiar that Artaud, the twentieth century's quintessential thinker of cruelty, would open his one book on theatre theory with a fundamentally "moral" concern. Culture, as it stands, and its concomitant construct of "civilization" "tyrannize" by operating externally to the lives that they affect. "Life itself," in all its profundity, remains both unknown and unsought as those who happen to be living it are allowed only approximate cultural representations (and misrepresentations) of what it could be. In response, Artaud desires a restoration of life by way of a physiologically affective theatre, a Theatre of Cruelty, as he names it, wherein spectatorial experience would become an essential exercise in liberation from the "tyrannical" culture of the interbellum French bourgeoisie — its art, politics, social codes, modes of production, and so on, all of which remain formally, spatially, and temporally cordoned off from any firsthand experience of the fullness of life. Taking as its primary task the subversion of bourgeois culture's removal from life, Artaud's theatre refuses its artistic inheritance while striving for the unthinkable: a perfect "coincidence" with - and ontological indistinguishability from — something called "life." The one doubles the other, but as neither representation nor simulacrum, neither mirror nor shroud; rather, this staged doubling must make it seem as though it is in fact life that doubles the theatre (as the book's title overtly suggests) and, as such, becomes empowered and allowed to emerge amongst the stale confabulations of "civilized" culture's more intellective or psychological pursuits. What the theatre

R.D. Crano lives, teaches, makes art, bakes bread, rides a bicycle, and reads books (mostly) in Columbus, Ohio. A Ph.D. candidate in the Department of Comparative Studies in the Humanities at The Ohio State University, he is writing a dissertation on poststructuralist ontologies of vision and visuality, the biopolitics of memory, and the evolution of cinematic and videographic technique and form. His work has appeared previously in Film-Philosophy and Senses of Cinema. 
can and should do is expose our domesticated faculties of perception to strange and provocative sensations. Such exposure is a fundamentally political activity, insofar as true politics always entails forcing something previously unperceived into a given perceptual field. ${ }^{2}$ Along these lines, Artaud's invocation of "tyranny" needs to be carefully weighed. Against the political operation that inscribes a necessary distance between ruler and ruled, we might extract from Artaud's critique a more immediate, undisciplined autonomy, a politics "coincident" with everyday life. ${ }^{3}$ In terms of stagecraft, this means challenging, on a number of fronts, the dominant text-bound mode of theatrical production by suffusing the spectatorial body in an undifferentiated multisensory milieu of non-representative, counter-mimetic impressions.

I argue for the primacy in Artaud's thought of this problem of reconciling culture and life. There seems to be a general tendency in Artaud scholarship to overlook the "moral" concerns that frame his text. Many regularly discussed threads in his oeuvre might be productively resituated in light of his historically specific anxieties over the increasing distance between "life" and its various public avatars - between what is supposedly interior and what is shared. An indispensable moral problem, I believe, conditions Artaud's many theatrical and theoretical creations. Cruelty, plague, alchemy, madness, and the like are but partial solutions, or rather different takes on the same foundational concern to reverse the trend of "present demoralization." "Though perhaps too often concealed by his contemptuous rhetoric, on the one hand, and poetic abstractions, on the other, Artaud's polyvalent "doublings," in the final analysis, offer us an ethic of rigorous humility and a politics of direct, unmediated action. In order to recover and critically reassess these lines of thought that he himself either failed or refused to make explicit, this essay takes as its point of departure those spectatorial forms of life that the Theater of Cruelty alternately destabilizes and extends.

"Talk of civilization and culture" obscures what is really at stake-namely, the "present" moment - as "never before." Such a claim to historical uniqueness demands a sociopolitical contextualization that many of Artaud's readers too often reduce to conjectures about his reaction to the bourgeoning totalitarian spectacles of interwar Europe. This investigation, however, necessitates a more nuanced approach. Recognition of the particularly tumultuous political culture of France in the 1930s affords a better sense of how, for Artaud, an increasingly tenuous political climate could smother life's barely flickering flame. The French Third Republic (1870-1940) was plagued by a seemingly unending string of scandals and crises, and a large part of Artaud's writing emerged from the era's most tumultuous years. From May 1932 to January 1934 alone, five governing coalitions came to power and promptly collapsed. The endlessly banal ministerial reorganizations that ensued spread anti-parlimentarian sentiments that had previously been the province of a small minority on the far right. Influenced by the meteoric rise of fascism in Italy 
during the preceding decades, the right had galvanized around a shared penchant for militaristic displays of strength and an exploitative fascination with parades. ${ }^{5}$ Artaud must have been disturbed, firstly, by what many historians have dubbed the "decadence" of French political culture during the Third Republic. ${ }^{6}$ But the manipulative spectacles generated by the predominantly monarchistic right were perhaps even greater cause for consternation, especially given their potential and clear intent to usurp the singular powers of the theatre. All told, it is less an impotent political culture than an impotent cultural concept of the political - one that circumscribes little more than petty affairs and reactionary resurgences - which motivates Artaud's impassioned calls to re-moralize the present, as it were, and reactivate life.

Although Artaud, unlike, say, Bertolt Brecht, refuses to adopt an explicit political platform for his theatre, his intent to restructure his spectator's constitutive relationship to space, time, and the world on the whole has a distinctly political import. In the theatre, the spectator doubles her role as a political, economic, and historical being. Within the space-time of a cultural sphere "coincident" with that of life, the political, economic, and historical subjectivity of one who so doubles herself is exposed as not just socially constructed and therefore mutable but also powerfully, profoundly inhospitable to "life." We can thus extract from Artaud a recognition that cultural dimensions are, in the modern age, the primary site for the production of (potentially counter-hegemonic) subjectivities. The theatre becomes the metaphorical factory floor on which individuals are constructed, exploited, and - with the evolution of cruelty - granted the potential to resist the normative, passive comportments to which they had been confined. Where self indulgence and righteousness rule in the political sphere, and where bourgeois culture only reinscribes, in one way or the other, this deprivation of life, Artaud posits an agitative theatre that communes with its audience via an unmediated presence incommensurate with concurrent figurations of subjectivity, linguistic representation, and functionally compartmentalized space and time. I will, first, reexamine Artaud's dramatic theory in light of his acute and curiously underappreciated investment in the potential (or perhaps virtual) "coincidence" of culture and life, and, second, explicate the moral, ethical, and political ramifications thereof. In turn, a rearticulation of his thoughts on presence, language, spectatorship, and the pragmatic concerns of the metteur-en-scène will help formulate a more precise sense of what is meant when readers, following his lead, invoke the concept of "life."

\section{The moralization of time}

"Present demoralization," in one sense, means nothing less than a demoralization of presence - the failure to appreciate the imminent possibilities for a coincidence of culture and life irreducible to the electoral politics of the center- 
left establishment or the spectacularized politics of the anti-parliamentarian right. The traditional Occidental theatre, according to Artaud's reading, encourages the passive consumption of "artistic" pleasures with little or no existential expenditure; little or no "risk" on the part of the egocentric viewing subject; and thus little or no engagement with the political, economic, and technological forces radically changing life outside the theatre space. In the age of the industrial-technological reproducibility of art, ${ }^{7}$ the task of putting culture and life into coincidence must take one of two tacks: either it renders life closer to industrial reproducibility, making each singular form of life more or less indistinct, or it attempts to rescue culture for life by sabotaging the machinery of mass reproduction. It should, over the course of this article, become clear that the Theatre of Cruelty adopts the first of these methods of coincidence. Just as past masterpieces are best left to the past, ${ }^{8}$ so too with past forms of life. Artaud's heated rejection of bourgeois notions of identity and selfhood, along with his obsession with his own becoming-machine, evinces a certain desire, on his part, to explore the latent potential of the new, often jarring reproduction technologies of the early twentieth century. Practically, this desire motivated a number of experiments that sought to introduce outside life, most frequently in the form of audio recordings, into the affective space of the theatre. ${ }^{9}$ The intended result was presumably the production of a liminal spacetime wherein "real" life could be continuously recycled, replayed, and called into question. And this threshold between culture and life, where the one regularly undergoes a topological deformation into the other, hinges as much on temporal reconfigurations as on spatial deconstructions. In the "present demoralization" of 1930s France, time itself, or a particular way of experiencing time, is at stake. Perversely, the interplay of live and recorded sounds - a feat made possible by dehumanizing industrial technologies - offers a presence fit to be called "moral," one that reverberates rather richly through time, a present resonant with the past that it has always already become.

Framing a cultural problem in terms of "life," Artaud identifies the ontological stakes of theatrical production, which ultimately fold into the processes of individuation by which the social body constitutes itself. Artaud's critique of "civilized culture," his revaluation of presence, and his implicit theorization of a "moral" resurgence all revolve around his sustained attack on the passively perceptive, disembodied spectator. In her study of the "imperceptibility of life" in Artaud's writing, Dorothea Olkowski advances a Bergsonian model that distinguishes two levels of spectatorial activity: selective perception and sensory-motor affection. Where the former affirms the intentional efficacy of the viewing ego, the latter - in its most heterogeneous state, free from all perceptive interests - "constitute[s] a world in motion, a world that vibrates with [the] multiple rhythms [of other beings]." ${ }^{10}$ For Olkowski, Artaud undercuts the sedimented habits of selective perception by forcing the spectator to continuously confront this 
vibratory world that constitutes perception but cannot itself ever be fully actualized or consciously considered in its totality. David Graver similarly charts Artaud's insistent disruption of spectatorial subjectivity, which he argues is achieved, in practice, through a reconfiguration of the geometrical boundaries of the theatre space. Surrounding its audience on all sides with a diffuse mise en scène, the Theatre of Cruelty strips its spectators of "the implicit authority of their all-encompassing gaze" and "does violence to [their] expectations for the innocuous pleasures of aesthetic consumption."

I would add to Graver's reading a supplemental, though perhaps anterior, interruption that Artaud incites on a temporal plane. Because we are dealing with vibrations, we must necessarily turn our thoughts toward time. As the "demoralizing" gap between culture and life widens, so too does that between self and other; the "tyrannical" circumscription and reified isolation of the spectatorial subject - individuated herein as a passive onlooker of both theatrical culture and political life-grows increasingly severe. From an ethical perspective, the theatre affords an experience of durations that are wholly other. Be they of gestures or screams, illuminations or overdetermined things, these other durations throw spectators back into their own duration with a resoundingly new sense of the fragility of their time.

Many of Artaud's ideas on art, life, and spectatorship would find resonance in the decades to come. Guy Debord's The Society of the Spectacle, for example, opens by similarly decrying how "everything that was directly lived has receded into a representation." 12 And more recently, Bernard Stiegler, perhaps the most astute, politically-oriented contemporary interpreter of the increasingly influential mid-century philosopher Gilbert Simondon, has argued that the technical-social milieu of the current "hyperindustrial" epoch threatens to absorb human lives into processes of individuation that are collective but not at all co-produced. ${ }^{13}$ This in mind, Artaud's most ardent concerns seem to portend the autocratic course that individuation and subjectivation would take as the century advanced. His experiments with the simultaneously destructive and creative forces of preindividual affects manifest a persistent effort to undermine what I call, following Debord and Stiegler, the necropolitics of everyday life. Along these lines I seek to recover an ethical dimension to Artaud's project, insofar as ethics takes as its most basic operation a critical engagement with how individuals - triangulating as they do culture and life_- "coincide."

Where Artaud calls for his spectacle participants to "dissolve into universality." 14 Gilles Deleuze (himself inspired by Artaud) discovers in Simondon a strikingly similar sentiment. The individual, according to Deleuze, is arrived at through a process of creative differentiation, a conversion of intensive affects into extensive signs. "Indi-differentiation," as he calls it, always carries with it a pre-individual component, a "reservoir of singularities," the identification of which makes possible 
a retroactive critical movement of de-differentiation that shares much with Artaud's pining for "universality." 15 Yet this universal dissolution of the spectatorial body means much more than a new mode of experiencing theatre; part of a larger struggle to actualize an intersubjective world and a genuinely co-productive model of transindividuation, it implies a complete reworking of political and cultural infrastructure outside of the time and space of the theatre. ${ }^{16}$ Geoffrey Baker asserts that Artaud's is "a transformative tragic politics that seeks to overcome unpalatable social regimes by interrogating the epistemological formations and structures of representation from which they spring." 17 There is thus a crucial link between language and culture, on the one hand, and sundry state and non-state governing apparatuses, on the other. Only through a transformation of culture - that primary site for the co-productions of subjectivity and resistance ${ }^{18}$ - might the almost comically unstable politics of interwar France be redeemed.

Occupying the gaps between self and other, culture and life, the threatening promise of the Theater of Cruelty entails constructing an affective presence where there had been only an alienating void, a presence that reverberates through time and is consonant with the whole of the past into which it invariably recedes and the future that interminably overrides its immediacy. The theatre, by imbuing the space of culture with a pulsating sense of life, presents what could not hitherto have been presented-namely, that void instantiated in the medium's so-called bourgeois mode. In affirming the theatre's unique potential for immanent, gesturohaptic affection prior to verbal representation, Artaud desires a theatre no longer dormant, no longer pacifying, reawakened to its ability and increasingly pressing need "to break through language in order to touch life." ${ }^{19}$ He theorizes faculties of visual and aural perception pushed to their respective limits, forced to a threshold of exteroceptive indistinction, each sense passing into the other. At their limit points, the separate faculties must confront at once those gestures previously subordinated to texts, as well as the hapticity - that primeval touch - at the heart of each ocular and aural sign. ${ }^{20}$ "The soul," Artaud asserts, "can be physiologically reduced to a skein of vibrations." ${ }^{21}$ His theatre, in turn, reconfigures its audience as an assemblage of such "physiologically reduced" souls who no longer perceive the theatre but become alchemically affected by it, corporeally overwhelmed by a field of visual and aural intensities from which linguistic representation must struggle to emerge. The spectatorial "soul" here collapses into a vibratory "skein," a tangled composite of no-longer-distinguishable sensations. ${ }^{22}$ "There is no transition from a gesture to a cry or a sound: all the senses interpenetrate." ${ }^{23}$ Visual and aural perceptions become con-fused as pure vibration, in a primordial chaos of sensation that can be captured neither by reflective thought nor the written word.

In a sense, Artaud bridges historical time, as the theatre he conceives transports participants to an epoch of humanity prior to the cultural devaluation of gesture and the hegemony of alphabetic writing (which the bourgeois theatre proudly 
inherits). This bridge is manifest most clearly in his will to access or reconstruct a preindividuated spectatorial milieu, and it evinces a theme that recurs throughout The Theater and Its Double-specifically, the need to create links, occupy gaps, and open thresholds - which explains why separation, in its many modes, ${ }^{24}$ remains the object of antagonism through much of this work. Between life and its cultural representation, an irremediable distance prevents direct access to the former while shoring up a widespread, superficial appreciation for the latter. Theatre-as-art is of only passing concern, as it is life itself that Artaud seeks to radicalize. And this life emerges, remarkably, precisely in the void between presence and representationthat crucial zone of space-time in which acculturated individuals and political subjects are continuously produced. In wiping away the transmitting medium with a signified thing, representation necessarily stifles one's affective relationship to one's near past. With the goal of restoring this relationship, Artaud's theatre works almost exclusively on the spectatorial body (on both individual and collective corporeal planes), utilizing the dormant somatic capacities of the form to finally exhaust the dramaturgical art of linguistic signification. By occupying the gaps, as it were-between signifier and referent, self and other, culture and life- the Theatre of Cruelty becomes a vehicle for the fundamental transformation of both individual and collective bodies. Theatrical revolution and the revitalization of life are thus, for Artaud, ontologically indistinguishable acts; each doubles the other in hopes of overcoming the stale complacency of modernity's spectator-citizen.

\section{Perspective, empire, and the birth of spectacular society}

In 1950s and 1960s Paris, the Situationists were transposing (without acknowledgment, of course) Artaud's position into an expressly socially and politically theorized field of action. Debord's aforementioned book, the group's seminal treatise, opens its dual critique of consumer capitalism and totalitarian politics with a distressing account of the "separation perfected" therein. ${ }^{25}$ Founded on multilateral social disintegration, the spectacle can only be overcome with a line of "active direct communication" ${ }^{26}$ very much like what Artaud had argued for the generation prior. In terms of the aesthetic agenda, cultural commodities would be replaced by "constructed situations," whereby processes of art and life intertwine to interrupt the state of things and open up new fields of sensory experience. In this sense, Situationist street theatre, urban derives, and agit-prop campaigns seem genuinely to realize his desire to breathe new meaning into the used-up signifier "life." A semi-scripted performative act in an otherwise non-theatrical space, their constructed situations exploit and draw energy from the conditions of boredom necessary to the reproduction of spectacle and concomitant modes of subjectivation. Distinctions between performers and spectators collapse; all simply become "livers," whose libidinal investment in spectacular representation becomes détourned in advancing "experimental forms of the game of revolution," ${ }^{27}$ which 
is of course nothing less than the "game" of life.

It should be no surprise that Debord pinpoints 1927 as the birth of spectacular society, coinciding precisely with Artaud's most formative production experiences. ${ }^{28}$ Though he refuses to provide empirical details of any sort, it may have something to do with European colonialism's need - having largely exhausted its extensive reach $^{29}$ - to adopt an intensive function, which would be rather well served by rapidly evolving technologies of image production. ${ }^{30}$ Turning inward, the imperial impulse revealed itself in the 1930s most significantly in forms of intra-continental conquest and (what Debord would later call) the "colonization of everyday life." Artaud's undertaking, in turn, is to reverse these "demoralizing" geopolitical and socioeconomic trends plaguing modern European life.

"When we speak the word 'life," Artaud says,

it must be understood that we are not referring to life as we know it from its surface of fact, but to that fragile, fluctuating center which forms never reach. And if there is still one hellish, truly accursed thing in our time, it is our artistic dallying with forms, instead of being like victims burnt at the stake, signaling through the flames. ${ }^{31}$

Foregoing any critical engagement with the subjects "formed" by political, economic, social, and cultural institutions, the bourgeois theatre of the 1930s operates in hiding, behind its text, its artistic formalities, its didactic values, and so on. ${ }^{32}$ It irrevocably alienates its viewing audience by positioning its enactments as distant, absent, and other than life. The live convergence of bodies and affects, which in fact constitutes all theatre, seems not to register within traditional modes of production. Subsequently, life here loses its "fragility" - its phantasmic presenceand becomes a mere "surface fact" set in a dormant dialectical tension with art, which functions only to depreciate both terms of the equation.

Artaud turns the imitative theatre of the bourgeoisie on its head, seeking to expose as derivative and wholly insufficient its mediated treatment of life, which perpetually lags behind the real life "touched" by a new theatre that takes as its ultimate project a sort of out-spectacularization of the spectacle of the state: "In the anguished, catastrophic period we live in, we feel an urgent need for a theatre which events do not exceed, whose resonance is deep within us, dominating the instability of the times. ${ }^{333}$ From the militaristic parade culture of the French far right and the scandal-ridden bureaucratic mainstream to the personality cults of Nazism and Stalinism and the increasingly visualized market capitalisms of England and the United States, ${ }^{34}$ Artaud finds himself suffocating in a generalized politics of appearance completely overrun by the hegemony of industrialized imageproduction. In the final analysis, the agglomeration of diverse spectacular regimes 
in interwar Europe made consumers of the masses and put "life" at a severe distance from its everyday incarnations. In return, Artaud offers a theatrical spectacle that more-than-appears - a counter-spectacle, if you will — that activates all the senses and forces a proprioceptive awakening of its newly potentiated audience. Where "formal dallying" preserves the culturally constructed bourgeois subject and satisfies one's intellective fancies, the Theatre of Cruelty, in repudiating such artifice, seeks a direct, unmediated relationship with the spectatorial body, what Derrida (in an essay on Artaud) names an "existence without signification." ${ }^{35}$

Where the speech elements of the traditional theatre fail to achieve true aural affect on account of their fidelity to a read (which is to say static, spatialized) text, Artaud's own timbral and rhythmic deformations of language render him the aforementioned victim at the stake. Indeed, far from signifying, his "signals" seek to touch "that fragile, fluctuating center" which, however "reached," cannot be made to comport with a "knowledge" adept only in "surface facts." The "life" that Artaud, the writer, "speaks," remains wholly averse to recognition-its forms always unsettled and evolving, its essence always there but impossible to identify or represent. Like Deleuze's concept of the virtual, "life" might be thought of as "real without being actual, ideal without being abstract." ${ }^{36}$ Whatever formal actualizations emerge from Artaud's take on the concept of life must remain just that: whatevers, inessential byproducts of his pragmatic working through of the most vital problem of them all-“demoralizing" separation.

\section{Gesture and/in language}

In "Metaphysics and the Mise en Scène," Artaud most precisely defines the parameters of language in his theatre:

To make metaphysics out of a spoken language is to make the language express what it does not ordinarily express: to make use of it in a new, exceptional, and unaccustomed fashion; to reveal its possibilities for producing physical shock; to divide and distribute actively in space; to deal with intonations in an absolutely concrete manner, restoring their power to shatter as well as to manifest something; $[\ldots]$ to consider language as the form of Incantation. ${ }^{37}$

In keeping with my politicized reading of sensation, "concrete" language-as incantation-makes things appear that should not appear, that in fact cannot appear under normal conditions. "To make metaphysics out of a spoken language" is to refuse the alphabeticization and grammatization (which again is to say the spatialization) of speech, to affirm the temporality of verbal presentation. The Theatre of Cruelty takes up linguistic deformation as the basis for the cultural 
and social change it seeks. In so doing, it preserves and recharges that which is obliterated by the written word and script-bound theatrical production - namely, the temporal continuity and gestural capacity of the human voice. ${ }^{38}$ Artaud thus draws our attention to the fact that the meaning of an expression is perpetually bound up in stylistics, in how it is said, in its rhythm and timbre, in the way its words have been illicitly lifted from past usage, and in its situational contingency - in the possibility that it could always have been semantically the same but vibrationally, affectively otherwise.

In linguistic terms, the arch concerns of demoralization and separation coalesce in the widely discussed gap between signifier and referent. Baker in fact argues that "Artaud explicitly ascribes the problem of the times to the space between signifier and referent." ${ }^{39}$ Having done with "closed, egoistic, personal art," Artaud intends to rupture the language of representation in which the bourgeois subject has remained comfortably couched. The theatre's dependence on sedimented forms shares much responsibility for the "present demoralization" of culture and life. Rather than "touch" the audience at an immanent, pre-intellective level, script-bound productions relate a writer to an audience through the intermediary characters that, to some degree, speak primarily for her or him. On the contrary, in the Theatre of Cruelty, normative signifying processes need to be suspended so that words and gestures might begin to take on the non-referential attributes of, for example, lighting or sound. All elements of the mise en scène boil down to "a skein of vibrations" $" 40$ that affects the spectator sub-sensically (which is to say psychically, collectively, and pre-individually) and so preempts the validation of her identity as a centrally positioned and internally coherent viewing subject.

Seeking the reunification of body and language, he asserts, "What the theater can still take over from speech are its possibilities for extension beyond words, for dissociative and vibratory action upon the sensibility." ${ }^{41}$ The outcome, I believe, is something like a radical humility in the face of semantic ambiguity. From the vibratory intercorporeality of the cruel theatre we can derive a new and antagonistic subjectivity produced when signs become "dissociated" from their signifieds, which had determined them to represent transcendentally rather than "really mean." In the community to come, the political community that the Theatre of Cruelty precipitates, humility and care respond not to what is said but to how such sayings occur, not to words per se but to "signals through the flames." Demanding a de facto reconsideration of who can be included and excluded from political life, sensation, rather than representation, must determine the nature and scope of social change. ${ }^{42}$ By attending more to the pre-linguistic, non-representational attributes of the mise en scène than to its formal and verbal production of meaning, Artaud distinguishes his theatre - on political grounds - firstly from that which seeks only to imitate and, in so doing, distance itself from life, but also from certain avant-gardist trends that similarly forego multisensory impact in favor of a strictly intellective engagement 
with its audience.

Drawing on Artaud among others, Julia Kristeva describes the two-fold functioning of language: on one hand is the symbolic, which grants referential meaning to the phonetic components; on the other hand is le semiotique, comprised of non-signifying movements - rhythm, timbre, intonation, and so on. Where the symbolic is spatial and referential, the semiotic is temporal and musical. ${ }^{43}$ Attempting to "break through language," the work of a "questionable subject-inprocess" such as Artaud serves as "a release for the anger of its time" and marks "the place where the social code is destroyed and renewed." ${ }^{44}$ We can thus assign to the Theatre of Cruelty a cathartic and restorative task: first, to affirm and take responsibility for the production of subjectivity and, then, to construct alternative modes of psychic and collective individuation more attuned to the "fragility" of life and the "rude and epileptic rhythm of [the] time[s]." 45

Taking inspiration from the canonized masterpieces, the traditional theatre fails even to recognize its potential to affectively dislocate the spectator at the pre-linguistic level that Kristeva so brilliantly theorizes. Likewise for the mere "dallying" of the formal avant garde, which achieves a fair amount of critical and popular success between the wars. That said, one of the more notable distinctions between the "demoralized" bourgeois and "dallying" avant-garde theatres, on the one hand, and Artaud's Theatre of Cruelty, on the other, lies in their respective conceptions and treatments of audience. The former address reified subjects; the latter assembles a spectatorial body inseparable from the immanent vibratory affects of the theatrical experience, then distributes that body along the coordinates of a revolutionary topology that continuously deforms culture into life, and vice versa. The cruel performance must repeatedly disrupt spectatorial perception and interpretive agency. And herein lies an unexpected movement towards humility, to which neither scholars nor practitioners have given much notice. On the flipside of Artaud's rejection of bourgeois culture lies the tacit affirmation of a moral code to come, one that perhaps can never be fully constituted but must nevertheless be struggled over perpetually. Any politics or culture that posits the individual as its primary operative unit would seem arrogant according to Artaud's schema, which, against "closed" art, values open, impersonal explorations of the collective unconscious. By rigorously delimiting the scope of human knowledge, by humbling - and even humiliating - the most prized faculties of enlightened modernity (i.e., thought and vision), by presenting an always incomplete moral code, the Theatre of Cruelty demands an unprecedented commitment of its spectators, upon whose affective capacities and intercorporeal permeability the whole production turns.

In reversing the trend of "depreciating everything," Artaud's theatre presents the "terrible and necessary cruelty which things can exercise against us." "Depreciation," it would seem, is the ironic result of excessive appreciation, 
whereby aesthetic discourse and thought gets reduced to idle talk, parlor chatter, blandly indiscriminate remarks. Responding to this trend, Artaud uses a variety of tactics to deform the word-things that comprise his language. Screamed words, for example, do much more than signify; like "signal[s] through the flames," they are more felt than heard. In "cruel" fashion, sonic things become tactile, pushing hearing into a zone of hapticity. "We are not free," he soberly admits, "and the sky can still fall on our heads. The theatre has been created to teach us that first of all." ${ }^{146}$ And: "My mind, exhausted by discursive reason, wants to be caught up in the wheels of a new, an absolute gravitation. ${ }^{" 47}$ Here gravity takes on strange new meaning as an indiscriminate force that unites all beings in their equal and unequivocal subjugation to its unrelenting constraint. In an odd twist, this experience should ultimately engender humility. (We are being "taught" after all, by this Chicken Little theatre.) Above all else then, Artaud's is a rigorous interrogation, first, of what Martin Jay has analyzed as the Cartesian perspectival scopic regime, ${ }^{48}$ and consequently of the Eurocentrism and colonial geopolitics that rose in its wake and were coming to a head in the multivalent industrializations of culture, party politics, and everyday life in the early decades of the twentieth century.

Yet we must be cautious in our endorsement of Artaud's project. It hardly needs to be pointed out that the most salient arbiters of "new, absolute gravitation" of 1930s Europe were the Nazi and Stalinist regimes. (Following Debord, we might also include the increasingly automated production and consumption patterns of capitalism's more "diffuse" spectacles.) Is Artaud simply succumbing to their surging popularity, or more specifically, that of the intensely dogmatic French far right? How, we must ask, does the political and ethical takeaway of his project remain distinct from these bourgeoning forces of the interwar milieu? What is it about his all-encompassing spectacles that prevents their being reduced to mere replications of the blind, frenzied espousal of a particular party cause? Artaud's own oeuvre leaves us little to go on in attempting to come to terms with these qualms. Instead, a further unraveling of the complex nature of Artaudian cruelty should yield an internally antagonistic, anti-identitarian politics in contrast with the conformist spectacular, ocularcentric politics dominant within and all around the French Third Republic.

Where "discursive reason"-which "exhausts" and is in turn exhausted by Artaud - purveys a subjectivity and concomitant moral code antithetical to the overwhelming sense of codependence roused by the forces of "absolute gravitation," cruelty, in the final analysis, "liberates" social and spectatorial bodies from "human individuality" and transcendentalist preoccupations by continually forcing them back onto an immanent plane. ${ }^{49}$ Cruelty is always in the service of what Artaud calls the "free exercise of thought," ${ }^{\circ 0}$ arrived at by forcing a humble attenuation to affective "undersides" and consequently exploding the orthodox acculturation 
of the faculty. Politically, Artaud's philosophy would seem to necessitate a violent interruption of Europe's imperial projects (and, more radical still, an interruption of anthropocentrism in general), which presume themselves untethered from any unifying, pan-continental (or trans-species) "gravitation." ${ }^{51}$ That the "necessity" of "gravitation" remains paradoxically coextensive with a peculiar sense of release suggests that Artaud is advocating not an end to thinking but a different style of thinking, a model of thought freed from the sort of "reason" that had found its geopolitical counterpart in the project of empire.

Uncompromising even in his theoretical explications, Artaud challenges us to escape the binaristic logic that opposes freedom to necessity. ${ }^{52}$ In thinking cruelty, we must vigilantly resist the disciplined inclination to separate and fashion such mutually exclusive terms. Founding its transformative agency on the incoherent "evidence of pure flesh," 53 Artaud's "wholly magical" works must liberate thoughtlike morality - from its rational structure to confront the hegemony of "discursive reason." Within its liminal space-time, the Theatre of Cruelty reveals the strict limits on intentional efficacy and exacerbates the fundamental decentrality of the self; but it must also turn out a signaling subject capable of newly living the everyday, and this is precisely its moral act.

\section{Toward an ontology of violence and a violent ontology}

The foundational issue for Artaud remains a question of style - that singular marker of critical contemporaneity. ${ }^{54}$ In cruelty - a mechanism the theatre (including the formally experimental avant-gardes) had hitherto left considerably underexplored — he finds the answer to his search for "a manner and language ... [in] touch with the rude and epileptic rhythm of our time." "P5 "Present demoralization" hinges, at least in part, on the theatre's failure to adapt stylistically to its social and historical situation. The "rude and epileptic" everyday life in 1930s Europe had yet to meet its cultural equivalent - the double from which it cannot tell itself apart and which thereby ruptures its ontological stability. Rather than creating its own time and confronting spectacular society with a rudeness and epilepticity all its own, the script-bound or formally dallying French theatre functions merely as a submissive, compulsory beat in the "rhythm of [the] times." Cruelty, as Artaud has it, must rid the theatre space of its "snobbish, precious, aesthetic mentalities" and open it to altogether less "mental" and more physiological modes of spectatorship. Revealing its space as a key site in the production of subjectivity, an ideal mechanism to discover new possibilities for pre- and trans-individuation, the theatre must reappropriate life from its current channels of control; it must realize its affective potential to serve as a prophylactic against the intellective tendencies of cultural elitism and the idolatry of the historically obsolete, textually reified masterpiece.

Where disembodied linguistic representation perpetually parries away affect and deep time, Artaud's twin deformations of culture and life seek to "touch" its 
spectators in a way that would undermine the state of all the social, political, and religious discursive regimes of his day. "Masterpieces of the past," he says, "are good for the past: they are not good for us. We have a right to say what has been said and even what has not been said in a way that belongs to us, in a way that is immediate and direct, corresponding to present modes of feeling, and understandable to everyone. ${ }^{556}$ It remains the task of art—-truly cruel art— to discover what these modes are and how precisely they can be reached by an expressive act no longer burdened by the demands of referentiality or intellective recognition. ${ }^{57}$ In contrast to his own affect-oriented "poetic language"-which perpetually "re-involves" its addressee in an equally "poetic place in reality"-Artaud derides what he calls "literary" expression for its fixity "in forms that no longer respond to the needs of the time." Alphabetized, discrete, and spatially inscribed, "literature" remains indifferent to the social and spectatorial body and to those technologies of modern society that organize and distribute it. The quickly escalating cultural valuation of literacy — as the most basic indicator of human aptitude - lies at the heart of bourgeois "tyranny." Artaud responds by making art itself illiterate. His aim is quite clear: the mise en scène, which includes the human voice and machinic noise as much as visible objects, must be experienced "immediately" and "directly" for "what [it] really [is]" — namely, a temporal tangle of vibrations and resonances and colliding, heterogeneous durations.

While critical work on Artaud has all too frequently pigeonholed him either as the theoretician of an impossible theatre or a metaphysician in an age that no longer has the conceptual space for metaphysical thought, ${ }^{59}$ Kimberly Jannarone documents an overwhelmingly positive critical response to Artaud's earlier productions with the Alfred Jarry Theatre (1926-28), making possible a reevaluation of his theoretical tracts of the 1930s with an eye towards the very real possibility of their materializations on and off stage. We might, I believe, accordingly understand his praxis with the Jarry Theatre as a constitutive component of the cultural revolution his later Theatre of Cruelty would more explicitly define - a revolution having, in the end, less to do with theatre than the social relations amongst the "general public." In the Jarry Theatre, Artaud would employ objets violemment vrais (literally, "violently real objects")—- "objects out of proportion that create gaps or lags, temporal disruptions" ${ }^{90}$ - to attain those de- and trans-formations of spectatorial perception that necessarily precipitate such revolution. Jannarone explains that, "as elements were heightened and denatured, their function became twofold. They called attention to themselves as sensory stimuli, as violently real, but they also pulled the scene out of the realm of the ordinary, thus giving it significance in a 'tangential' realm, be it symbolic or 'magical."' and Its Double, Artaud ambitiously promises to "rhythmically" entwine such "violently real objects" with equally "violent" manipulations of light, sound, and verbal utterance, each element collapsing in on itself before achieving any sort of 
self-enclosed meaning - all mingling on a plane of immanence that delimits the individuation of the spectatorial body. Spectacular violence, one among many means of perceptive and ontological interference at the disposal of the metteur en scène, remains vital to Artaud's theatre precisely for its atmospheric weight, its entirely unscripted (and unscriptable) permeation of characters, audience, and milieu, even, as Deleuze has it, before any action occurs. ${ }^{62}$ Enshrouded in an ensemble destined for such Cruel ends, individuals cannot but disappear in the overwhelming sensation of responsibility for the impulses herein released. ${ }^{63}$

Here, plagued by this unbearable responsibility forced on spectators by Artaud's absolute cruelty, they finally achieve the "touching" of culture and life- the spatial and temporal separations that had determined their mutual alienation now breached by the hitherto unthought moral power of affect. The Theatre of Cruelty folds spectators simultaneously into both culture and life, so that they, placed too close to achieve traditional perspective, must enter into a mode of haptic spectatorship, "exceeding" and "extending beyond" and fundamentally altering vision itselfthat "noblest of human senses." ${ }^{64}$ In the end, this leveling of the hierarchy of perceptive faculties must be seen as a political act through and through. Culture and life coincide where bodies become de-individuated and trans-individuated, where identities collapse into the mise en scène. The spectacular politics and attendant cultural entities against which Artaud writes betray their own fundamental inadequacy in sustaining the "life" that Cruelty seeks to expose.

When "all the senses [begin to] interpenetrate," as it were, the verbalized linguistic sign "act[s] like [a] silent blow . . . an inflammatory image thrust into our abruptly wakened heads." The signifier, traditionally conceived as more or less transparent, here remains utterly inseparable from the rhythmic, timbral, and tonal qualities of its coming to presence. The leap to referential meaning loses its coherence in a movement of immanent (and imminent) becoming. Reiterating the double nature of the objets violemment vrais conjured within the Jarry Theatre's mise en scène, the cruelly silent sign confronts the audience as at once fantastically illogical yet undoubtedly real-itself a thing to be experienced physiologically as a "blow" that remains dumb in the face of our intellective demands. Alongside "noises that are unbearably piercing," "new ways of spreading light," "objects of strange proportions," and a wholesale "abandon[ment of] the architecture of present-day theater," verbal articulations that accentuate the innate gesturo-hapticity of language work to undercut some of our most deeply engrained perceptual habits. Artaud's is a "theater space ... utilized not only its dimensions and volume but, so to speak, in its undersides" - which is to say in its utterly invisible aspects, in its temporal existence. Cruelty demands a radical temporalization to set ablaze the values and norms of a society whose subjects remain tragically ill-equipped for the moral task of "coinciding" with life. The "inflammatory image" to which they awake is, to be precise, an obscured image, an image of time. The "undersides" 
augment indefinitely those counter-effective spatial separations circumscribing the traditional theatre. Temporalized from the start, Artaud's space is never static, never identical to itself, a virtual space constantly vibrating, throwing itself back and forth through time - a strategic site for the distribution of intensities, constituted by affects, sensations, and vibrations rather than characters, dialogue, plot, and form. Grounded in topological deformation and the ever disruptive coming into being of what was once misconstrued as a fully constituted space, the Theatre of Cruelty seeks to "reforge the chain between what is and what is not," 65 between a presently extant bundle of sensations and all those past and future with which it resonates.

For all its overt animosity, Artaud's project at last proves to be an experiment in immanent community foundation. "The chain between what is and what is not" is held loosely together by a spectatorial body through which vibrations are relayed, multiplied, and transformed, forming an intercorporeal group subject held open to the aleatoric promise of things past and things to come. Here, disruptions, reversals, and hesitations are essential attributes of ecstatic care. This genuinely coindividuated community is fragile, to say the least, and the antagonistic production of new subjectivities entails a tremendous risk, a risk that Artaud, uniquely sensitive to the "rude and epileptic rhythms" of interbellum France, tortuously bore in both art and life alike. Some seventy years later and no less spellbound by the mass reproduction of images in all spheres of everyday life, we discover that in Artaud, just as he once discovered in the superabundant impressions of the Balinese theatre, "IT IS WE WHO WERE SPEAKING" —impossibly_-all along. ${ }^{66}$

\section{Notes}

1. Antonin Artaud, The Theater and Its Double, trans. Mary Caroline Richards (New York: Grove P, 1958) 7. "The Theater and Culture," the book's preface, was the last of its essays to be written.

2. Jacques Rancière defines politics as a taking part of those who have no part, a making count of what had gone uncounted, or an appearance of what had not hitherto appeared. I follow this line of thinking, though, for reasons that will become clear later in this essay. I want to avoid his visual emphasis in favor of a more corporeally and proprioceptively inclined approach. (See especially Rancière, Disagreement: Politics and Philosophy, trans. Julie Rose (Mineapolis: U of Minnesota P, 1999.)

3. I am here suggesting a certain resonance between Artaud and a long line of generally dissident thinkers of immanent politics, from Spinoza and Nietzsche to Deleuze and Guattari.

4. I use "problem" and "solution" here in the sense elaborated in the early work of Gilles Deleuze - the problem as idea. For Deleuze, a problem-idea is unconscious, extra-propositional, and entirely without resemblance to the actual solutions to which it gives rise. In a sense, the problem-idea delimits the scope of an experiment in creative biological, political, or (as in our case) aesthetic evolution. Deleuze, Difference and Repetition, trans. Paul Patton (New York: Columbia U P, 1995) 162-64, 267.

5. On the general history of the Third Republic following the First World War, see, for example, Philippe Bernard, The Decline of the Third Republic, 1914-1938, trans. Thony Forster (Cambridge: Cambridge U P, 1988); on the French far right in the decade of Artaud's writing, see Robert Soucy, French Fascism: The Second Wave, 1933-1939 (New Haven: Yale U P, 1997).

6. For a recent summary of the "decadence" debate in French historiography, see Peter Jackson, "Post-War Politics and the Historiography of French Strategy and Diplomacy Before the Second World War," History Compass 4.5 (2006): 870-905. 
7. This point gestures, if only in passing, to the strange affinity between Artaud and his contemporary Walter Benjamin, whose duly famous essay on technology and art was first published in 1935. Walter Benjamin, "The Work of Art in the Age of Mechanical Reproduction," Illuminations (New York: Harcourt Brace Jovanovich, 1935) 217-252.

8. Artaud, The Theater and its Double 74. I take up this point in more detail in the final section of the present work.

9. See Denis Hollier, "The Death of Paper, Part Two: Artaud's Sound System," October 80 (Spring 1997): 36-38.

10. Dorothea E. Olkowski, "Eluding Derrida: Artaud and the Imperceptibility of Life for Thought," Andelaki: Journal of the Theoretical Humanities 5.2 (2000): 192-3.

11. David Graver, "Antonin Artaud and the Authority of Text, Spectacle, and Performance," Contours of the Theatrical Avant-Garde: Performance and Textuality, ed. James M. Harding (Ann Arbor: U of Michigan P, 2000) 51.

12. Guy Debord, The Society of the Spectacle, trans. Donald Nicholson-Smith (New York: Zone Books, 1994) 12. I will return to this text, and to the Situationist project in general, in greater detail below.

13. I will take up Simondon, by way of Deleuze, in the following pages. For Stiegler's work on pre-, trans-, and collective individuation, see "Anamnesis and Hypomnesis," Technicity, ed. Arthur Bradley and Louis Armand. (Prague: Litteraria Pragensia, 2006) 15-41; "Teleologics of the Snail," Theory, Culture, and Society 26 (2009): 33-45; "The Time of Cinema," Tekhnema 4 (1998): 62-118.

14. Artaud, The Theater and Its Double 25.

15. Deleuze's most developed analysis of individuation (as "indi-different/ciation") occurs in the "asymmetrical synthesis" chapter of Difference and Repetition. Defined in terms of a signal-sign system and grounded only in the absolute groundlessness of difference-in-itself, the Deleuzean-Simondonian individual is opposed to the traditional philosophical concept of the I and the self, which operate in accordance with the very laws of identity and recognition that Difference and Repetition sets out to destroy (see especially pages 246-257). Simondon's philosophy of psychic and collective individuation finds another strong ally in Deleuze and Guattari's resurrection of the Scholastic concept of haecceitythe immanent this-ness indeterminate, irreducible Whole. Haecceity models an alternative mode of individuation to that reinscribed in the traditional Occidental theatre, which produces self-same, egoistic, interpreting subjects who blindly transcend the immanent affective place of a given performance. Within the revitalized presence of the mise en scène, the spectator no longer has experiences to be organized and made sense of but becomes physiologically constructed and organized by them; we "cease to be subjects to become events, in assemblages that are inseparable from an hour, a season, an atmosphere, an air, a life." Gilles Deleuze and Felix Guattari, A Thousand Plateaus: Capitalism and Schizophrenia, trans. Brian Massumi (Minneapolis: U of Minnesota P, 1987) 262. The Theatre of Cruelty, wherein individuation becomes liberated from its institutionally circumscribed possibilities, seems to demand that the spectatorial body be conceived of in such terms.

16. Along these lines we might also consider the secondary, broader use of the term mise en scène, which arose in both the French and the English shortly after the original theatrical usage. This usage extends to include "the settings, surrounding, or background of any event or action" (Oxford English Dictionary). Add to this the performers, spectators, and the action itself and we have precisely the notion of haecceity as developed by Deleuze and Guattari.

17. Geoffrey Baker, "Nietzsche, Artaud, and Tragic Politics," Comparative Literature 55:1 (2003): 2 .

18. For more on the micropolitics of subjectivation see Jason Read's close readings of Marx's Grundrisse from a perspective much informed by Deleuze, Michel Foucault, and Antonio Negri. The Micropolitics of Capital: Marx and the Prehistory of the Present (Albany: SUNY, 2003).

19. Artaud, The Theater and Its Double 13.

20. Brian Rotman has charted the transductions of gesturo-hapticity through the historicalmediological apparatuses of speech, alphabetic writing, and motion capture technologies. He argues that gesture, long ago surpassed as the dominant medium of human communication, is nevertheless present in speech (as prosody) and writing (in the forms of poetry and prose). Motion-capture technologies, for their part, reintroduce gesture into human life to a degree that was not possible through the hegemonic epochs of speech and alphabeticism. See Becoming Beside Ourselves (Durham: Duke U P, 2008) 22-28. Similarly, the Italian philosopher Giorgio Agamben has attempted to explore the significance of gesture for a radical politics whose paradigmatic form is the general strike: "What characterizes gesture is that 
in it nothing is being produced or acted, but rather something is being endured and supported. The gesture, in other words, opens the sphere of ethos as the more proper sphere of that which is human." In this way, he continues, "The gesture is the exhibition of a mediality: it is the process of making a means visible as such. It allows the emergence of the being-in-a-medium of human being and thus it opens the ethical dimension for them." "Notes on Gesture" and "Marginal Notes on Commentaries on the Society of the Spectacle," Means Without End: Notes on Politics, trans. Vincenzo Binetti and Cesare Casarino (Minneapolis: U of Minnesota P, 2000) 57-58.

21. Artaud, The Theater and Its Double 135.

22. Deleuze and Guattari's conceptual extrapolation of Artaud's "body without organs" indicates "a fusional multiplicity that effectively goes beyond any opposition between the one and the multiple. A formal multiplicity of substantial attributes that, as such, constitutes the ontological unity of substance. The Body without Organs is the field of immanence of desire" (A Thousand Plateaus 154). This bodyArtaud's body, the spectatorial body - remains resistant to organization at every turn, its interpretive faculties rendered useless in the theatre's superabundant emission of undifferentiated sensations.

23. Artaud, The Theater and Its Double 135.

24. Among these technologies of separation must be included alphabetic writing, which spatializes, depersonalizes, and makes discrete a mode of communication that had been continuous and holistic and had required the co-presence of interlocutors (see Rotman and Stiegler). The mass reproducibility of alphabetic writing in the nineteenth and early twentieth centuries, along with the literacy boom that ensued, make human separation (read: "demoralization") all the more commonplace.

25. See for example: "Being isolated - and precisely for that reason — the spectacle is the locus of illusion and false consciousness; the unity it imposes is merely the official language of a generalized separation." Also, "The spectacle is [...] the perfection of separation within human beings." Early in the text, Debord also references "the separation of worker and product" and that of images from reality. "Separation," just to make sure his point is clear, "is the alpha and omega of spectacle." Guy Debord, Society of the Spectacle, trans. Donald Nicholson-Smith (New York: Zone, 1994) 12, 13, 18, $20,21$.

26. 29,116 .

27. "Preliminary Problems in Constructing a Situation," Situationist International 1 (1958).

28. Guy Debord, Comments on Society of the Spectacle, trans. Malcolm Imrie (New York: Verso, 1990), 3 .

29. Edward Said points out that, by 1914, eighty-five percent of the habitable globe was under European rule of some form. Orientalism (New York: Vintage, 1979) 8.

30. Filling in Debord's gaps, Jonathan Crary cites several important events of 1927 vis-à-vis what he calls "technologies of attention:" the perfection of television, the birth of sound film, and the coterminous rise of Nazism and Stalinism - all of which to some degree can be classified in terms of an inwardly turned colonizing impulse. "Spectacle, Attention, Counter-Memory" October 50 (1989): 96-107.

31. Artaud, The Theater and Its Double 13.

32. For a thorough discussion of theatre politics in the 1930s, see Martin Harries, "Forgetting Lot's wife: Artaud, spectatorship, and catastrophe" Yale Journal of Criticism 11.1 (1998): 221-239.

33. Artaud, The Theater and Its Double 84.

34. Debord neatly categorizes spectacular societies as either concentrated or diffuse, the former designating autocratic totalitarianisms, the latter "free market" capitalist states.

35. Jacques Derrida, Writing and Difference, trans. Alan Bass (Chicago: U of Chicago P, 1978) 175.

36. A refrain that recurs throughout Deleuze's oeuvre, this formula for virtuality is first posited as a paraphrase of Proust in Proust and Signs, trans. Richard Howard (Minneapolis: U of Minnesota P, 2004) 58.

37. Artaud, The Theater and Its Double 46.

38. Cf. Rotman, op. cit.; Cf. Stiegler, op. cit.

39. Geoffrey Baker, "Nietzsche, Artaud, and Tragic Politics" Comparative Literature 55.1 (2003): 12. In keeping with my preoccupation with temporality, I would suggest that the time between signifier and referent remains of equal concern. This, however, is perhaps too extensive a problem to handle in any depth here. For Artaud, the signifier and the referent must become one and the same, and the resultant counter-representational presence, rather resembling the Greek ideal of direct engagement in a collectively produced polis, would be Artaud's political space-time par excellence.

40. Artaud, The Theater and Its Double 135.

41. Artaud, The Theater and Its Double 89. 
42. In an excellent recent study, David Panagia explicates what he names "the political life of sensation." As he understands it, sensation is "neither sense nor perception . . . but rather the heterology of impulses that register on our bodies without determining a body's nature or residing in any one organ of perception." Following Rancière, he argues that "politics happens when a relation of attachment or detachment is formed between heterological elements: it is the part-taking in the activities of representation that renders perceptible what had previously been insensible." David Panagia, The Political Life of Sensation (Durham: Duke U P, 2009) 2-3.

43. Julia Kristeva, Revolution in Poetic Language, trans. Margaret Waller (New York: Columbian U P, 1984) 19-89.

44. Kristeva, "From One Identity to an Other," Desire in Language, trans. Thomas Gora, Alice Jardine, and Leon Roudiz (New York: Columbia U P, 1980) 125, 132.

45. Artaud, The Theater and Its Double 75.

46. 79 .

47. Artaud, "Manifesto in Clear Language," Selected Writings (Berkeley: U of California P, 1976) 108.

48. The critique of which provides the impetus for Martin Jay's sweeping history of antiocularcentrist discourse. Downcast Eyes: The Denigration of Vision in Twentieth-century French Thought (Berkeley: U of California P, 1994).

49. Artaud, The Theater and Its Double 116. The "liberated life" of which Artaud speaks is, in the most radical interpretation, Bergson's élan vital - life outside of species differentiation. According to this largely unrecognized conceptual precursor of Artaudian cruelty, each formed species (in our case, "man") and each specific incarnation of that species (e.g. individual "men") signal the arrested movement of a much more powerful duration. See Henri Bergson, Creative Evolution, trans. Arthur Mitchell (New York: Modern Library, 1944). For Deleuze's reading of élan vital, see Gilles Deleuze, Bergsonism, trans. Hugh Tomlinson and Barbara Habberjam (New York: Zone, 1990) 91-114.

50. Artaud, The Theater and Its Double 47.

51. Artaud's production The Conquest of Mexico was to bring the Theatre of Cruelty to fruition. Though ultimately unrealized, the play is worth mentioning here for its scenario's persistent critique of European colonialism, as well as for "its immediacy and all the allusions it permits to problems of vital interest for Europe and the world." The play, according to Artaud, "revives in a brutal and implacable way the ever active fatuousness of Europe" and "broach[es] the alarmingly immediate question of colonization and the right one continent thinks it has to enslave another" (The Theater and Its Double 126).

52. Following Susan Sontag's seminal analysis of the fragmentary nature of Artaud's oeuvre, Robert Lublin locates a certain discursive cruelty precisely in these rhetorical tendencies, in Artaud's paradoxical style. "The written page becomes the site of the Theatre of Cruelty," where "Artaud is able to assault his readers rigorously and continuously ... by challenging their ordinary method of engaging a text." See Sontag, "Artaud: An Essay," Antonin Artaud: Selected Writings (Berkeley: U of California P, 1988) xx, xxiv; and Robert I. Lublin, "Cadences of Cruelty: Artaud's Discursive Performance," Theater Symposium 8 (2000): 63, 69. Artaud's elliptical style and violently juxtaposed imagery are, according to Lublin, meant to expose the constructed nature of our reading habits and mark his attempt to divert the cohesive organization of impressions, here not of the theatre spectator but of her analogue - the reader of a text.

53. Artaud, "Manifesto on Clear Language," Selected Writings 108. "I believe only in the evidence of what stirs my marrow, not in the evidence of what addresses itself to my reason ... There is for me an evidence in the realm of pure flesh which has nothing to do with the evidence of reason. The eternal conflict between reason and the heart is decided in my very flesh, but in my flesh irrigated by nerves."

54. See Agamben's definition of the contemporary in "What is the Contemporary?" What is an Apparatus? and Other Essays, trans. David Kishik and Stefan Pedatella (Paolo Alto: Stanford U P). "The contemporary is he who firmly holds his gaze on his own time so as to perceive not its light, but rather its darkness. All eras, for those who experience contemporariness, are obscure. The contemporary is precisely the person who knows how to see this obscurity, who is able to write by dipping his pen in the obscurity of the present" (44).

55. Artaud, The Theater and Its Double 75.

56. 74.

57. Derrida famously deconstructs the tension in Artaud between the desire for pure presence 
and the necessity of its perpetual deferral through representation. He describes work as always being "the work of death," in that it trades the vibratory quality of artistic becoming for the static readability of formal documentation, or what he calls "breath" for "literality." See Writing and Difference 183. Derrida characteristically dismisses Artaud's metaphysics without much consideration for its staged actualizations. Kimberly Jannarone's research into the Alfred Jarry Theatre (see below) and Laura Cull's "How Do You Make Yourself a Theater Without Organs," Theatre Research International 34.3 (2009): 243-255, among others, have made great strides in qualifying some of Derrida's most derisive remarks.

58. Artaud, The Theater and Its Double 92, 75, 107.

59. Most take it for granted that his attempts to realize the Theater of Cruelty (with Les Cenci in particular) had failed in all respects, and the trend in academic circles has more often than not been to follow Sontag and Derrida in theorizing this assumed failure. For Derrida, Artaud's attempts at conjuring pure presence always fall back into representational modes. Along similar lines, Harries suggests a "resistance to history" implicit in Artaud's thought that hinders the de-subjectification that he hopes to achieve. Helga Finter additionally cites Artaud's own post-war writings that signal a pessimistic disbelief in the possibility for therapeutic theatre. For a more engaging reading of Les Cenci from within the framework of Artaud's theories on cruelty, see Jane Goodall, Artaud and the Gnostic Drama (Oxford: Oxford U P, 1994).

60. Kimberly Jannarone, "The Theater Before Its Double: Artaud Directs in the Alfred Jarry Theater," Theatre Survey 46.2 (2005): 256.

61. 265 .

62. In his discussion of the impulse-image in the films of Joseph Losey, Deleuze articulates an "originary violence of impulses" that "is always 'in act' but ... too great for action." See Cinema 1: The Movement-Image, trans. Hugh Tomlinson and Barbara Habberjam (Minneapolis: U of Minnesota P, 1986) 137. This, I believe, is perhaps the most concise articulation of the sort of violence Artaud aims for in his cruel theatre. Interestingly enough, Artaud remains a touchstone in Deleuze's second cinema volume as well. In theorizing the collapse of the sensory-motor schema and the movementimage of classical cinema, Deleuze offers a brief case study of Artaud's short-lived relationship with the filmic medium, which quickly dissolved once it became clear that the potential for physical shock and forced thought was no less lost on cinema than it had been on the theatre. Only after World War II, after the Nazi cooptation of cinematic power had run its course, would film achieve the tasks Artaud had set for it as early as 1925. Cinema 2: The Time-Image, trans. Hugh Tomlinson Minneapolis: U of Minnesota P, 1989) 162-166.

63. Deleuze, Cinema 1138.

64. I refer to Jay's treatment of the longstanding discourse, from Plato to Descartes and beyond, on the "nobility" of vision. See Downcast Eyes, 21-82.

65. Artaud, The Theater and Its Double 27.

66. 67 (Artaud's capitalization). 